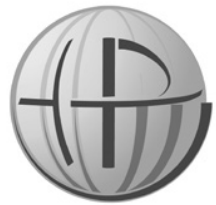

\title{
LESZEK KWIECIŃSKI
}

http://orcid.org/0000-0003-3678-6132

Uniwersytet Wrocławski

leszek.kwiecinski2@uwr.edu.pl

DOI: $10.35765 /$ HP.1895

Horyzonty Polityki

2020, Vol. 11, No 37

OPEN ACCESS

\section{Rola miast w kreowaniu partnerstw na linii biznes - nauka. Przykład rozwiązań wrocławskich}

\section{Streszczenie}

CEL NAUKOWY: Głównym celem artykułu jest wskazanie możliwości tworzenia i rozwoju partnerstw na linii nauka-biznes $\mathrm{z}$ akcentem na aktywną rolę władz lokalnych (miejskich) na przykładzie działań Wrocławia.

PROBLEM I METODY BADAWCZE: Głównym problemem badawczym jest analiza zakresu i form aktywności władz publicznych szczebla lokalnego w kreowaniu obszarów rozwoju lokalnego na podstawie teorii reżimów oraz koncepcji samorządu ułatwiającego. Metodami użytymi do operacjonalizacji tak zdefiniowanych celów są: metoda systemowa mikrozasięgu, wskazująca na znaczenie miasta w budowaniu partnerstw lokalnych, metoda instytucjonalno-prawna opisująca warunki formalne Programu MOZART oraz neoinstytucjonalizm racjonalnego wyboru pozwalający określić efekty Programu, a techniką badawczą są dane zastane oraz wywiad minifokusowy przeprowadzony z członkami zespołu zarządzającego Programem.

PROCES WYWODU: Hipoteza badawcza dla powyżej przedstawionego problemu stanowi, że współczesne wyzwania rozwojowe stawiane przed miastami z jednej strony wymuszają a z drugiej wspierają działania władz lokalnych w kreowaniu powiązań typu government to citizien oraz business to public. Główne założenie artykułu odnosi się do zmieniającej się roli miast w procesach europeizacji. Przy zastosowaniu teorii reżimów i koncepcji samorządu ułatwiającego określono przesłanki nowych ról miasta $\mathrm{w}$ procesach tworzenia interdyscyplinarnych partnerstw. Artykuł kończy analiza ilościowo-jakościowa dotychczasowych efektów funkcjonowania Programu.

Sugerowane cytowanie: Kwieciński, L. (2020). Rola miast w kreowaniu partnerstw na linii biznes - nauka. Przykład rozwiązań wrocławskich. Hory- 
WYNIKI ANALIZY NAUKOWEJ: W wyniku analizy dowiedziono, iż aktywna rola samorządu lokalnego sprzyja kreowaniu partnerstw międzysektorowych.

WNIOSKI, INNOWACJE, REKOMENDACJE: Jednym z głównych obszarów współczesnej aktywności miasta jest tworzenie partnerstw międzysektorowych, angażujących zasoby zarówno świata nauki, jak i gospodarki. Swego rodzaju innowacją organizacyjną jest Program MOZART, realizowany przez miasto Wrocław od 2012 r. Inicjatywa ta inspirowana rozwiązaniami europejskimi, ale jednocześnie silnie wpisana i wyrastająca z potrzeb endogennych, pozwala samorządowi uruchamiać współpracę i aktywność podmiotów publiczno-prywatnych. Jest to zatem przykład działania tzw. samorządu ułatwiającego.

\section{SŁowa KLUCzowe:}

partnerstwa, rola miast, samorząd ułatwiający

\section{Abstract}

THE ROLE OF CITIES IN CREATING

ON THE BUSINESS - SCIENCE PARTNERSHIPS. AN EXAMPLE OF WROCŁAW SOLUTIONS

RESEARCH OBJECTIVE: The main purpose of the article is to indicate the possibility of creating and developing of the science-business partnerships with an emphasis on the active role of local (municipal) authorities on the example of Wrocław's activities.

THE RESEARCH PROBLEM AND METHODS: The main research problem is the analysis of the scope and forms of activity of public authorities at the local level in creating areas of local development based on the theory of regimes and the concept of the enabling government. The methods used to operationalize the objectives are: the micro-range system method, indicating the importance of the city in building local partnerships, the institutional and legal method describing the formal conditions of the MOZART Program, and neo-institutionalism of rational choice allowing to determine the effects of the Program, and the research technique is the existing data and mini-focus interview with members of the Program management team.

THE PROCESS OF ARGUMENTATION: The research hypothesis for the problem presented above is that contemporary development challenges posed to cities on the one hand enforce and on the other support the activities of local authorities in creating government to citizen and business to public relations. The main premise of the article relates to the changing role of cities in Europeanization processes. Using the theory of regimes and the concept of the enabling government, the premises for new city roles in the processes of creating 
Rola miast w kreowaniu partnerstw na linii biznes - nauka

interdisciplinary partnerships were determined. The article ends with a quantitative and qualitative analysis of the current effects of the Program.

RESEARCH RESULTS: As a result of the analysis, it was proved that the active role of local government favors the creation of intersectoral partnerships.

CONCLUSIONS, INNOVATIONS, AND RECOMMENDATIONS: One of the key areas of the city's contemporary activity is the creation of crosssectoral partnerships, engaging the resources science and the economy partners. The MOZART Program, implemented by the city of Wrocław since 2012, is a kind of organizational innovation. This initiative, inspired by European solutions, but at the same time strongly inscribed and growing out of endogenous needs, allows the local government to launch cooperation and activity of public-private entities. It is therefore an example of the enabling government, part of a proactive strategy of city management and its development.

\section{KeYwORDS:}

partnership, role of the city, enabling government

\section{WSTĘP - WZROST ZNACZENIA MIAST}

Zyskująca na znaczeniu od początku lat 90. XX w. zasada subsydiarności stała się z czasem mechanizmem wzrostu znaczenia nie tylko regionów (NUTS 2), ale także jednostek terytorialnych niższego rzędu, jak np. miast (NUTS 5). Szczególnie duże miasta, powyżej 500 tysięcy mieszkańców, stały się swego rodzaju centrami glokalnymi, które zaczęły nadawać impulsy rozwojowe dla swojego otoczenia. Miasta zaczęły zatem tworzyć i wspierać swój specyficzny lokalny ekosystem, który organizuje życie danego terytorium w każdym aspekcie: społecznym, ekonomicznym czy politycznym. To właśnie w miastach zlokalizowane są najważniejsze instytucje publiczne i siedziby wielu firm.

O rosnącym znaczeniu miast w rozwoju społeczno-gospodarczym świadczą także dane liczbowe, np. podczas gdy w 1950 r. tylko 30\% światowej populacji żyło w ich granicach, to już w 2014 r. odsetek ten zwiększył się do prawie 54\%. Do roku 2050 wskaźnik ten ma osiągnąć $60 \%$ (United Nations, 2014, s. 4). W państwach członkowskich Unii Europejskiej w strukturach miast mieszka prawie 359 milionów osób, co stanowi 72\% wszystkich mieszkańców, do 2050 r. wskaźnik 
ten ma wzrosnąć do prawie $80 \%$. Europejskie miasta wytwarzają 85\% PKB całej UE oraz zapewniają miejsca pracy dla 74\% czynnych zawodowo (Miejski wymiar polityki UE, 2014, s. 4).

Fenomen wzrastającej roli miast opisywało wielu badaczy, m.in. Benjamin Barber (miasta i ich przywódcy jako nowy wymiar władzy), Richard Florida (miasta jako potencjał wzrostu - fenomen 3T - talent, tolerancja, technologia), Manuel Castells (miasta jako węzły glokalne) czy Saskia Sassen. Ta ostatnia badaczka opisywała m.in. funkcjonowanie miast $\mathrm{w}$ czterech podstawowych wymiarach, w których miasta (Sassen, 2012):

- stają się silnie scentralizowanymi punktami dowodzenia w organizacji światowej gospodarki;

- są głównymi lokalizacjami dla firm z zakresu technologii, finansów i wyspecjalizowanych usług;

- są miejscami produkcji (zwłaszcza w innowacjach), oraz

- same stają się rynkami dla produktów i wytwarzanych innowacji.

Zasadnicza dla koncepcji miast globalnych jest ich rola w przepływie kapitału i informacji, a więc bycie węzłem procesu, który polega na ciągłym ruchu przebiegającym pomiędzy endogennymi zasobami a globalnymi miastami (Sassen, 1991, s. 25).

Podobną wizję miasta przedstawiają również autorzy unijnego raportu „Miasta przyszłości, wyzwania wizje i perspektywy”. Dla nich miasta są miejscami, w których tworzy się innowacje i nadaje impulsy do rozwoju gospodarczego całych regionów. Według definicji Komisji Europejskiej utworzonej wraz z ekspertami OECD, aby dana jednostka osadnicza mogła być uznana za miasto we współcześnie zachodzących procesach globalizacji i regionalizacji, powinna spełniać następujące warunki (Miasta przyszłości. Wyzwania, wizje, perspektywy, 2011, s. 11-16):

- musi składać się z co najmniej jednej gminy (lokalnej jednostki administracyjnej),

- co najmniej połowa mieszkańców musi zamieszkiwać centrum miasta,

- centrum miasta liczy co najmniej 50000 mieszkańców.

Z przytoczonych powyżej argumentów wynika jednoznacznie, iż zarówno czynniki ilościowe (liczba mieszkańców, tworzone miejsca pracy, generowany PKB, a także dynamika tych zmiennych), jak i czynniki jakościowe wskazujące na miasta jako kreatorów sieci 
współpracy, kształtowania procesów innowacyjności i przedsiębiorczości, niejako predestynują miasta do odgrywania jednej z głównych ról w procesach rozwoju społeczno-gospodarczego. Powyższe fakty znajdują także potwierdzenie, a co więcej wzmocnienie, w toczącym się procesie europeizacji.

\section{MIASTA W PROCESIE EUROPEIZACJI}

Wzrost znaczenia miast jako istotnych graczy w procesach społeczno-gospodarczych wyjaśniają koncepcje Multi-Level Governance (Piattoni, 2010) czy Networks Policy (Beyme, 2005, s. 249-255). Jedną z głównych cech obu tych koncepcji jest wzrost interakcji zachodzących pomiędzy wieloma poziomami zarządzania i zachowań aktorów biorących udział w całym procesie europeizacji. Szczególnie w ujęciu MLG można wskazać dwa koncepty odnoszące się do wzrastającej roli miast w kreowaniu współpracy pomiędzy zdywersyfikowanymi funkcjonalnie i zasobowo podmiotami. Mowa tu o ujęciu interactive governance oraz experimentalist governance. Pierwsze $\mathrm{z}$ nich, interactive governance, oznacza konieczność zarządzania interaktywnymi arena$\mathrm{mi}, \mathrm{z}$ których powstają różnego rodzaju sieci (np. sieci miast EUROCITIES) czy partnerstwa (np. publiczno-prywatne). Celem takiego zarządzania jest formułowanie, promowanie i osiąganie wspólnych celów za pomocą środków wymiany, wdrażania i mobilizowania idei, regulacji, zasobów i aktorów. $Z$ kolei experimentalist governance wskazuje na odwoływanie się do innowacyjnych metod w zarządzaniu złożonymi procesami. Z jednej strony zatem mowa tu o wszelkiego typu nowych formach zarządzania (new public management czy new public governance), a z drugiej o zdywersyfikowanym zarządzaniu nowymi przestrzeniami (arenami) współpracy (przedsiębiorczość). Bardzo często główną rolę w tej formie zarządzania odgrywają aktorzy niebędący władzami centralnymi w danym państwie, czyli np. miasta (Torfing, Peters, Pierre, Sorensen, 2012).

Pragmatyczny wymiar przywołanych powyżej koncepcji teoretycznych odnoszących się do wzrastającej roli miast w procesie europeizacji można zauważyć od 2007 r. Swego rodzaju punkt wyjścia stanowi Karta Lipska na rzecz zrównoważonego rozwoju miast europejskich, przyjęta właśnie w 2007 r. Wskazywano tam na 
zintegrowane podejście do polityki rozwoju miasta, charakteryzujące się zaangażowaniem podmiotów gospodarczych, publicznych i społecznych na rzecz procesu, w ramach którego następuje koordynacja najważniejszych obszarów polityki miejskiej. Silny nacisk kładziony jest na potrzebę godzenia interesów, co sprowadza się do tworzenia różnego typu partnerstw, których uczestnikami mają być władze publiczne, obywatele oraz przedsiębiorcy (Moterski, 2010, s. 127). W ślad za Kartą Lipską nastąpiło na szczeblu supranarodowym przyspieszenie działań odnoszących się do zdecydowanego podkreślenia roli miast $\mathrm{w}$ procesie europeizacji. Wskazać tu można Komunikat Komisji Europejskiej z 18 lipca 2014 r. zatytułowany „Miejski wymiar polityki UE - kluczowe elementy agendy miejskiej UE" (COM(2014)0490), Rezolucję PE z 9 września 2015 r. w sprawie miejskiego wymiaru polityki UE, Pakt Amsterdamski ustanawiający pogram rozwoju miast w UE, uzgodniony 30 maja 2016 r., Konkluzje Rady z 24 czerwca 2016 r. w sprawie Agendy Miejskiej dla UE, Sprawozdanie Komisji z 2016 r. na temat stanu europejskich miast czy wreszcie ostatnie Sprawozdanie PE z czerwca 2018 r. w sprawie roli miast w ramach instytucjonalnych Unii (2017/2037(INI)).

Z przywołanych koncepcji teoretycznych, jak i praktycznych działań formalno-instytucjonalnych wyraźnie wynika, iż proces wzmacniania znaczenia miast nabrał wyraźnego przyspieszenia począwszy od pierwszej dekady XXI w. Bazując na powyższych przesłankach, należałoby zatem znaleźć właściwe dla nauk o polityce i administracji ramy teoretyczne, które pozwalałyby analizować ową podmiotowość miasta w złożonych procesach społeczno-gospodarczych. Jedną z możliwych propozycji takiej analizy może być koncepcja samorządu ułatwiającego wywodząca się z teorii reżimów.

\section{SAMORZĄD UŁATWIAJĄCY, CZYLI \\ OD STATYCZNEGO DO DYNAMICZNEGO KREOWANIA PARTNERSTW}

Jedną z teorii politologicznych, które mogą stanowić ramę analityczną dla opisu nowej dynamiki władz miejskich we współczesnych procesach rozwoju, jest teoria reżimów (ang. regime theory), 
a w omawianym przypadku reżimów miejskich. Centralnym punktem teorii reżimów jest pojęcie kompleksowości. Aby działać kompleksowo, sektor publiczny musi łączyć swoje możliwości $\mathrm{z}$,pozarządowymi/pozapolitycznymi” aktorami. Sektor publiczny i prywatny tworzą w ten sposób reżimy umożliwiające wspólne działanie. Reżim jest w takim przypadku definiowany jako „nieformalna, ale stosunkowo stabilna grupa posiadająca dostęp do zasobów (z uwzględnieniem zasobów władzy instytucjonalnej). Dostęp ten umożliwia jej trwały wpływ na podejmowanie decyzji w określonym obszarze realizacji polityki publicznej" (Stone, 1998, s. 11). W ramach reżimów nie istnieje formalna hierarchia, stąd teoria ta jest spójna z procesami indukowanymi z poziomu europejskiego, jak MLG czy teorii sieci. Nie ma tu jednego kierunku działania i kontroli. Podkreśla się raczej jej sieciowy charakter i współpracę między zaangażowanymi podmiotami. Raz ustanowiona współpraca postrzegana jest jako wartość wymagająca ochrony ze strony wszystkich "sygnatariuszy".

Jak już wspomniano powyżej, głównym przedmiotem zainteresowania władzy nie jest kontrola i dominacja, ale zdolność do osiągania celów. C. Stone wprowadza rozróżnienie pomiędzy power over (władzą nad) a power to (wpływem potrzebnym do osiągnięcia celu). Samorządy nie będą zatem współpracować jedynie z tymi, którzy mają największą siłę polityczną ale raczej z grupami, które mają zasoby istotne dla osiagnięcia celów strategicznych.

W kontekście tak rozumianych założeń teorii reżimów pojawia się pojęcie samorządu ułatwiającego (eng. enabling government), który stara się stwarzać innym warunki do działania, zamiast sam je bezpośrednio wykonywać. Praktyczna realizacja tej koncepcji sprowadza się do przyjęcia zasady polegającej na odkrywaniu i przewidywaniu u klientów gminy rodzących się przyszłych potrzeb na usługi publiczne i wczesne, uprzedzające podejmowanie działań celem ich zaspokojenia (Masse, Rajabifard i Williamson, 2008, s. 5-20). Tak ukierunkowane przez włodarzy gminnych zarządzanie rozwojem lokalnym prowadzi do tego, że klienci gminy otrzymują aktualne, dostosowane do ich bieżących potrzeb produkty miejsca (produkty terytorialne) (Kamosiński, 2017, s. 186). A. Szromnik zauważa, że główną przesłanką dla produktu terytorialnego (miejsca) ,,jest możliwość zaspokojenia potrzeb własnych osób, instytucji i ich grup dzięki czerpaniu z zasobów miejscowych o charakterze naturalnym, 
infrastrukturalnym, społecznym, kulturowym i intelektualnym" (Szromnik, 2008, s. 118).

Samorząd ułatwiający może przybrać zróżnicowane formy swojej aktywności, poprzez które to generuje lub sprzyja generowaniu owych produktów terytorialnych. Jedną z form tej aktywności jest wspieranie tworzenia partnerstw, do których zaliczają się działania z zakresu przedsiębiorczości, rynku pracy, innowacyjności i konkurencyjności. Celem zasadniczym takich partnerstw jest zdyskontowanie współpracy między sektorami publicznym i prywatnym na rzecz szeroko pojętego rozwoju miasta.

Do innych, szczegółowych celów tworzenia partnerstw lokalnych zaliczyć również można (Matusiak, 2001, s. 252-254):

- wprowadzanie mechanizmów konkurencji w wykorzystaniu środków publicznych;

- łączenie środków publicznych z prywatnymi oraz możliwości pozyskiwania środków zewnętrznych dla lokalnych przedsięwzięć prorozwojowych i infrastrukturalnych;

- rozwój nowoczesnych form transferu technologii, wspierania przedsiębiorczości i marketingu lokalnego.

Według L. Gilejko i R. Towalskiego partnerstwo jest ważnym czynnikiem kreującym zmiany i ich dynamikę, a przez to stymulującym sukcesy przedsiębiorstw i stabilny rozwój gospodarki. Sprzyja także wyższej produktywności i elastyczności organizacyjnej, wpływając przez to na zmiany poziomu innowacyjności czy zmiany jakościowe (Gilejko i Towalski, 2002, s. 8).

W literaturze opisującej wszelkiego rodzaju partnerstwa powstające na styku publiczno-prywatnym wyróżnia się pięć rodzajów powiązań (Vlachopoulou i Manthou, 2003, s. 3):

1. Business to business (B2B), czyli przedsiębiorstwoprzedsiębiorstwo, typowy przykład zawiązywania się wszelkiego rodzaju powiązań i struktur klastrowych.

2. Business to consumer (B2C), czyli przedsiębiorstwo-klient, $\mathrm{z}$ tym że pojęcie klient jest rozumiane bardzo szeroko, tzn. zarówno jako dostawca, jak i odbiorca danego dobra lub usługi.

3. Consumer to consumer (C2C), czyli konsument-konsument.

4. Business to public (B2P), czyli przedsiębiorstwo-otoczenie społeczne, a więc wszelkiego rodzaju partnerstwa publiczno-prywatne. 
5. Government to citizien (G2C), czyli instytucja publicznaobywatel i jest to forma ustanowienia zakresu partycypacji wszelkiego typu instytucji społeczeństwa obywatelskiego $\mathrm{w}$ procesach zarządzania regionem czy miastem.

Przykładem zastosowania koncepcji samorządu ułatwiającego realizowanego $\mathrm{w}$ odniesieniu do partnerstw lokalnych zawierających w sobie logikę G2C oraz B2P jest Miejski Program Wsparcia Partnerstwa Szkolnictwa Wyższego i Nauki oraz Sektora Aktywności Gospodarczej MOZART realizowany od 2012 r. przez samorząd Wrocławia.

\section{PROGRAM MOZART JAKO NARZĘDZIE BUDOWANIA PARTNERSTW NA LINII NAUKA-BIZNES}

Niniejsza część artykułu została podzielona na dwa fragmenty. W pierwszym $z$ nich opisano formalno-instytucjonalne aspekty funkcjonowania tego programu. W drugim $\mathrm{z}$ kolei wskazano na cały proces tworzenia się tej inicjatywy, ocenę jego mocnych i słabych stron, a także dotychczasowych efektów. Ten drugi fragment oparty jest na danych ilościowych pozyskanych z Biura Współpracy z Uczelniami Wyższymi Urzędu Miejskiego we Wrocławiu, które jest jednostką odpowiedzialną za realizację tego Programu. Ponadto do analizy zastosowano informacje pochodzące $\mathrm{z}$ wywiadu minifokusowego przeprowadzonego 13 marca 2020 r. z członkami zespołu obsługującego ten Program.

Miejski Program Wsparcia Partnerstwa Szkolnictwa Wyższego i Nauki oraz Sektora Aktywności Gospodarczej MOZART realizowany jest na mocy uchwały Rady Miejskiej Wrocławia nr XXIX/652/12 z dnia 5 lipca 2012 r. z późn. zm. Dodatkowo Program ten jest jednym z działań, które służą realizacji sektorowej Strategii Rozwoju Przedsiębiorczości Miasta Wrocławia „Przedsiębiorczy Wrocław 2030”. Strategia ta, będąca dokumentem operacyjnym wobec Strategii Miasta Wrocławia 2030, ma na celu systematyzację działań i przedsięwzięć, które już obecnie są prowadzone przez władze miasta. Głównym celem niniejszej Strategii jest wskazanie kierunków rozwoju i sposobów wsparcia przedsiębiorczości we Wrocławiu, a w konsekwencji 
wzmocnienie potencjału ekonomicznego Wrocławia. Za konieczny warunek jej realizacji uznaje się opracowanie modelu współpracy pomiędzy jednostkami miasta, innymi instytucjami administracji publicznej, instytucjami otoczenia biznesu, uczelniami i przedsiębiorstwami oraz jego wdrożenie. Sformułowanie misji Wrocławia w zakresie wspierania przedsiębiorczości nawiązuje do misji ujętej w "Strategii Wrocław 2030”, a mianowicie „Wrocław miastem mądrym, pięknym, zasobnym - miastem, które jednoczy i inspiruje" (Strategia, 2019, s. 4-5).

Celem Programu MOZART jest wsparcie wrocławskiego rynku pracy poprzez umożliwienie firmom dostępu do intelektualnego potencjału naukowców. W ramach programu miasto udziela finansowego wsparcia partnerstwom naukowo-biznesowym na realizację zgłoszonych przez nie projektów z różnych dziedzin, takich jak: biotechnologia, medycyna, budownictwo, informatyka, robotyka, technologia produkcji spożywczej, budownictwo, projektowanie przemysłowe, zarządzanie przedsiębiorstwami, logistyka oraz wielu innych. Udział w Programie daje firmie możliwość skorzystania z potencjału intelektualnego naukowca i wykorzystania jego specjalistycznej wiedzy na rzecz rozwoju przedsiębiorstwa. Naukowiec natomiast zyskuje możliwość pracy w środowisku biznesowym i wykorzystania swojej wiedzy w praktyce. Program trwa 12 miesięcy, przy czym co miesiąc naukowiec jest zobowiązany do świadczenia w danym przedsiębiorstwie 32 godzin pracy. Zatem elastyczna formuła Programu pozwala naukowcowi na łączenie pracy na rzecz przedsiębiorstwa z dotychczasową pracą na uczelni. O dofinansowanie projektów mogą się starać partnerstwa zainicjowane przez:

- naukowca, który uzyskał co najmniej stopień naukowy doktora $\mathrm{i}$ jest zatrudniony na uczelni lub $\mathrm{w}$ instytucie w charakterze pracownika badawczo-dydaktycznego albo badawczego oraz

- przedsiębiorcy zatrudniającego pracowników na terenie Wrocławia.

Tytułem realizacji projektu naukowiec otrzymuje comiesięczne wynagrodzenie w wysokości 3200 PLN brutto, które jest płatne ze środków budżetowych miasta. Przedsiębiorca nie ponosi żadnych dodatkowych kosztów, zobowiązany jest natomiast wydelegować osobę sprawującą opiekę nad naukowym partnerem programu (zaangażowanym naukowcem) na terenie firmy. 
Od 2012 r. zostało przeprowadzonych osiem edycji Programu, w ramach których wsparto 222 partnerstwa. Analizując wielkość przedsiębiorstw biorących udział w Programie, można zauważyć, że dominują mikroprzedsiębiorstwa i małe przedsiębiorstwa, które stanowią blisko 70\% wszystkich podmiotów gospodarczych korzystających z Programu (patrz tab. 1).

Tabela 1

Udział przedsiębiorstw wedtug kategorii w ramach poszczególnych edycji Programu MOZART

\begin{tabular}{|c|c|c|c|c|c|c|c|c|c|}
\hline $\begin{array}{c}\text { Kategoria } \\
\text { przedsiębiorstwa }\end{array}$ & $\stackrel{N}{N}^{\mathbb{N}}$ & 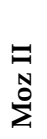 & $\begin{array}{l}\text { J } \\
\sum_{\Sigma}^{\circ}\end{array}$ & $\begin{array}{l}Z \\
\text { Z } \\
\sum_{i}^{0}\end{array}$ & $\begin{array}{l}> \\
\stackrel{N}{\Sigma} \\
\sum\end{array}$ & $\begin{array}{l}S \\
\text { N } \\
\sum_{\Sigma}^{0}\end{array}$ & $\begin{array}{l}\Xi \\
\stackrel{N}{N} \\
\stackrel{0}{\Sigma}\end{array}$ & $\begin{array}{l}\text { 目 } \\
\text { N } \\
\sum_{\Sigma}^{0}\end{array}$ & \\
\hline Mikro- & 10 & 13 & 14 & 15 & 10 & 8 & 13 & 14 & 97 \\
\hline Małe & 6 & 2 & 2 & 8 & 8 & 9 & 9 & 7 & 51 \\
\hline Średnie & 6 & 3 & 8 & 3 & 4 & 7 & 1 & 3 & 35 \\
\hline \multirow[t]{2}{*}{ Duże } & 3 & 5 & 6 & 3 & 8 & 5 & 3 & 6 & 39 \\
\hline & 25 & 23 & 30 & 29 & 30 & 29 & 26 & 30 & 222 \\
\hline
\end{tabular}

Źródło: opracowanie własne na podstawie danych uzyskanych z Biura Współpracy z Uczelniami Urzędu Miejskiego Wrocławia.

Analizując zaangażowanie pracowników naukowych poszczególnych uczelni, wyraźnie widać dominację przedstawicieli Politechniki Wrocławskiej, na kolejnych miejscach ze zbliżonymi wynikami plasują się pozostałe uczelnie wrocławskie, jak: Uniwersytet Ekonomiczny, Uniwersytet Przyrodniczy, Uniwersytet Wrocławski i Uniwersytet Medyczny (patrz tab. 2). 
Tabela 2

Udział pracowników naukowych według reprezentowanej uczelni w ramach poszczególnych edycji Programu MOZART

\begin{tabular}{|c|c|c|c|c|c|c|c|c|c|}
\hline Uczelnia & $\stackrel{N}{\stackrel{N}{\Sigma}}$ & $\begin{array}{l}\text { I } \\
\stackrel{N}{2}\end{array}$ & $\begin{array}{l}\text { 目 } \\
\text { No } \\
\sum\end{array}$ & $\begin{array}{l}Z \\
\sum_{\Sigma}^{0}\end{array}$ & $\begin{array}{l}> \\
\sum_{i}^{0}\end{array}$ & $\begin{array}{l}S_{N} \\
\sum^{N}\end{array}$ & $\begin{array}{l}\vec{J} \\
\sum \\
\sum\end{array}$ & $\begin{array}{l}\text { 目 } \\
\text { No } \\
\sum\end{array}$ & \\
\hline Politechnika Wrocławska & 9 & 11 & 12 & 18 & 17 & 11 & 18 & 14 & 110 \\
\hline Uniwersytet Ekonomiczny & 3 & 4 & 7 & 4 & 5 & 2 & 1 & 2 & 28 \\
\hline Uniwersytet Przyrodniczy & 1 & 3 & 4 & 4 & 1 & 4 & 3 & 6 & 26 \\
\hline Uniwersytet Wrocławski & 8 & 2 & 4 & 0 & 1 & 2 & 1 & 5 & 23 \\
\hline Uniwersytet Medyczny & 0 & 1 & 0 & 0 & 3 & 2 & 3 & 0 & 9 \\
\hline Akademia Sztuk Pięknych & 0 & 0 & 2 & 0 & 1 & 2 & 0 & 2 & 7 \\
\hline \multirow[t]{2}{*}{ Inne } & & & & & & & & & 19 \\
\hline & & & & & & & & & 222 \\
\hline
\end{tabular}

Źródło: opracowanie własne na podstawie danych uzyskanych z Biura Współpracy z Uczelniami Urzędu Miejskiego Wrocławia.

Powyżej przedstawione dane, wskazujące na zdecydowaną dominację naukowców Politechniki Wrocławskiej i Uniwersytetu Ekonomicznego, doskonale korelują z tzw. rodzajem transferowanej wiedzy (patrz tab. 3). Wśród realizowanych partnerstw przeważa transfer wiedzy technicznej (126) oraz ekonomicznej (32), pozostałe projekty odnosiły się do zagadnień biologiczno-chemicznych (26) czy humanistycznych (7).

Tabela 3

Realizowane partnerstwa w podziale na rodzaj transferu wiedzy w ramach poszczególnych edycji Programu MOZART

\begin{tabular}{|c|c|c|c|c|c|c|c|c|c|}
\hline Transfer wiedzy & $\sum^{N}$ & $\begin{array}{l}= \\
\sum^{N} \\
\end{array}$ & 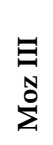 & $\begin{array}{l}Z \\
\text { N } \\
\sum\end{array}$ & ${ }_{\substack{N \\
\Sigma}}^{>}$ & \begin{tabular}{l}
5 \\
$N$ \\
\multirow{2}{*}{}
\end{tabular} & 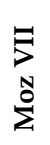 & 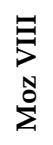 & $\begin{array}{l}\text { 节 } \\
\text { 心 }\end{array}$ \\
\hline Biologiczno-chemicznej & 3 & 1 & 0 & 2 & 4 & 3 & 7 & 6 & 26 \\
\hline Ekonomicznej & 3 & 4 & 9 & 4 & 5 & 3 & 0 & 4 & 32 \\
\hline Humanistycznej & 2 & 1 & 1 & 0 & 2 & 0 & 0 & 1 & 7 \\
\hline Innej & 4 & 2 & 5 & 2 & 2 & 7 & 2 & 7 & 31 \\
\hline \multirow[t]{2}{*}{ Technicznej } & 13 & 15 & 15 & 21 & 17 & 16 & 17 & 12 & 126 \\
\hline & 25 & 23 & 30 & 29 & 30 & 29 & 26 & 30 & 222 \\
\hline
\end{tabular}

Źródło: opracowanie własne na podstawie danych uzyskanych z Biura Współpracy z Uczelniami Urzędu Miejskiego Wrocławia. 
Analizując dane ilościowe związane z realizacją Programu MOZART, należy wreszcie poddać analizie kosztochłonność przedsięwzięcia dla pomiotu, który finansuje ową inicjatywę, czyli Gminy Wrocław. W tabeli 4 przedstawiono wartości budżetowe poszczególnych edycji tego Programu. Jak wynika z przedstawionych danych, koszt jednej edycji Programu to kwota około 1 miliona złotych, co daje łączną wartość w ciągu ośmiu lat ponad 9 mln PLN.

Tabela 4

Budzet realizowanych edycji Programu MOZART

\begin{tabular}{|c|c|c|}
\hline Edycja & Liczba partnerstw & Budżet [PLN] \\
\hline 2012/2013 (Moz I) & 25 & 1044000 \\
\hline 2013/2014 (Moz II) & 23 & 902717 \\
\hline 2014/2015 (Moz III) & 30 & 1257535 \\
\hline 2015/2016 (Moz IV) & 29 & 1239097 \\
\hline 2016/2017 (Moz V) & 30 & 1181307 \\
\hline 2017/2018 (Moz VI) & 29 & 1212800 \\
\hline 2018/2019 (Moz VII) & 26 & 1180160 \\
\hline \multirow[t]{2}{*}{ 2019/2020 (Moz VIII) } & 30 & 1105280 \\
\hline & 222 & 9122896 \\
\hline
\end{tabular}

Źródło: opracowanie własne na podstawie danych uzyskanych z Biura Współpracy z Uczelniami Urzędu Miejskiego Wrocławia.

Przedstawione powyżej dane ilościowe zostały następnie uzupełnione danymi jakościowymi, które pozyskano przez autora w ramach przeprowadzonego wywiadu minifokusowego z osobami realizującymi Program MOZART w Urzędzie Miejskim Wrocławia ${ }^{1}$. W trakcie wywiadu zostały poruszone następujące kwestie:

1. Przesłanki uruchomienia Programu MOZART.

1 Wywiad minifokusowy (Mini FGI) został przeprowadzony przez autora 13 marca 2020 r. w siedzibie Biura Współpracy z Uczelniami Wyższymi, Departamentu Prezydenta Miasta ze wszystkimi osobami zaangażowanymi 
2. Cele władz miejskich dla tworzenia programów partnerstw na przykładzie Programu MOZART (odwołanie do dokumentów strategicznych, operacyjnych).

3. Ocena zaangażowania przedstawicieli nauki oraz przedsiębiorstw w realizację Programu MOZART.

4. Najlepsze praktyki, najlepsze efekty (rezultaty) Programu.

5. Identyfikowane problemy/słabości partnerstw.

6. Cele partnerstw, które są najczęściej osiągane.

7. Postulowane kierunki ewolucji Programu czy innych inicjatyw w zakresie wsparcia partnerstw na linii nauka-biznes.

Analiza przesłanek uruchomienia Programu MOZART wyraźnie wskazuje, iż była ona tożsama z założeniami koncepcji samorządu ułatwiającego. Została bowiem wyartykułowana potrzeba ze strony podmiotów gospodarczych, które od 2000 r. zaczęły lokować swoje inwestycje we Wrocławiu oraz aglomeracji wrocławskiej, a także kiełkujących z nich start-upów lub korporacyjnych spin-offów. Wskazywano także na zbieżność innych przesłanek, jak doświadczenia z realizacji pierwszych projektów unijnych i inicjatyw unijnych (widoczny wpływ procesu europeizacji miast). W 2012 r. został sporządzony przez ekspertów OECD raport na temat Wrocławia odnoszący się do zagadnień funkcjonowania szkolnictwa wyższego w kontekście rozwoju miasta, gdzie jedną z istotnych rekomendacji była potrzeba uruchomienia oraz propagowania programu współpracy partnerskiej między nauką a biznesem animowanej przez miasto (Puukka, Dubarle, Goodard, Hazelkorn, Kuczera, 2013, s. 199-205). W rezultacie w 2012 r. rozpoczęto realizację I edycji Programu MOZART.

Powyżej opisane przesłanki uruchomienia Programu MOZART zostały wpisane w toczące się od początku 2005 r. procesy europeizacji, a w szczególności w cele tzw. nowej Strategii Lizbońskiej. Cele miasta w zakresie kreowania partnerstw i współpracy między nauką a biznesem można datować na 2005 r., kiedy ówczesny Przewodniczący KE J.M. Barroso ogłosił inicjatywę powołania Europejskiego Instytutu Technologicznego (obecny Europejski Instytut Innowacji i Technologii z siedzibą w Budapeszcie). „Pierwszym miastem europejskim, które

w Program MOZART, tj. z Tomaszem Janosiem (dyrektor Biura), Moniką Sochacką (zastępca dyrektora) oraz Anną Gil (koordynator Programu MOZART). 
odpowiedziało na tę inicjatywę, był właśnie Wrocław, było wiadomo, że jest to program wysokiego ryzyka". Rozpoczęła się realizacja tego wyzwania nazwana w mieście "programem EIT+". Głównym jego celem było to, aby utworzyć interdyscyplinarną infrastrukturę badawczą zorientowaną na współpracę nauki i biznesu.

W trakcie trwających kilka lat starań o pozyskanie dla Wrocławia prawa lokalizacji siedziby EIT unaoczniła w pełni władzom Wrocławia również to, że

ustawa o samorządzie gminnym nie daje prezydentowi praktycznie żadnych narzędzi do realizowania współpracy na linii nauka-biznes, np. finansowania działań badawczych, dydaktyki, okazało się, że nie ma żadnych narzędzi. Potrzeba było stworzenia takich instrumentów, rodzaju ,"think tanku”, który wspierałby i tworzył narzędzia rozwoju regionalnego, wspierał rozwoju akademii i III misji uczelni. MOZART miał być takim instrumentem wsparcia działań miasta skierowanym do przedsiębiorstw i wykorzystujący potencjał uczelni.

Jak zauważyli respondenci,

Celem działania miasta było katalizowanie współpracy poprzez udzielanie wsparcia samodzielnie zdefiniowanym partnerstwom, tam gdzie widać wysoki potencjał planowanej współpracy, a gdzie do tej współpracy mogłoby nie dojść gdyby nie interwencja miasta".

Z przytoczonych fragmentów wywiadu wyłania się proces uświadomionego wpisania potrzeb środowisk gospodarczych oraz działań miasta $\mathrm{w}$ trendy płynące $\mathrm{z}$ poziomu supranarodowego. Wykorzystano zatem zarówno inicjatywy Komisji Europejskiej, a także rekomendacje OECD i w ten sposób MOZART stał się od kilku lat jedną z ważnych inicjatyw kształtujących rozwój Wrocławia przy udziale aktywnego, ułatwiającego i inspirującego samorządu.

Ta rola władz miejskich jest potrzebna i zasadna, szczególnie gdy podda się ocenie zaangażowanie przedstawicieli nauki oraz przedsiębiorstw w realizację idei partnerstw, będącej modus operandi Programu MOZART. Zaangażowanie przedsiębiorców, a przede wszystkim korporacji nie jest duże, gdyż

jeśli na etapie wdrażania tego typu podmioty miałyby odpowiedzieć jakimkolwiek zaangażowaniem po swojej stronie, np. 1 godziną pracy 
menadżera wysokiego szczebla, odpowiedź jest - nie. Jakikolwiek nakład pracy po stronie korporacji jest zawsze kwestionowany.

Z drugiej strony uczelnie jako instytucje są w dalszym ciągu dość bierne. „Partnerstwa są zazwyczaj inicjowane przez naukowców lub firmy, które gdzieś wcześniej się już poznały na konferencjach, przy innych projektach, mają do siebie zaufanie".

Przechodząc do oceny jakościowej efektów Programu MOZART, respondenci zostali poproszeni o wybranie najlepszych praktyk (rezultatów) Programu. Wskazano tu kilka projektów, które do dziś są kontynuowane i które pozwoliły realizującym je podmiotom rozwinąć skalę czy zakres działalności, a także przyniosły wymierne efekty rynkowe. Do najciekawszych projektów zaliczono:

- Działania prowadzone przez Etno Cafe - technologia parzenia kawy (zimna kawa).

- Browar Stu Mostów - browar rzemieślniczy i restauracja - firma, która w Mozarcie opracowywała innowacyjną technologię produkcji pieczywa z udziałem odpadów z produkcji browarniczej.

- Cydr Meli Melum - technologia procesowa.

- SensDX - ultraczuła platforma sensoryczna do szybkiej detekcji i potwierdzania bądź wykluczania infekcji wirusowych.

- Poprawę wytrzymałości przęseł mostowych we Wrocławiu;

- Barki przemysłowe - design i ergonomia;

- Aplikację muzyczną na potrzeby udźwiękowienia gier firmy TECHLAND;

- Strategię wspierającą zarządzaniem ZOO we Wrocławiu.

- Powstanie nowych firm, około pięciu firm typu start-up.

- W historii programu zdarzyły się też przypadki niezwykle dynamicznego rozwoju przedsiębiorstwa w kilka lat następujących po udziale w programie (np. dwukrotnym) - co w przypadku jednej z firm biotechnologicznych zakończyło się debiutem giełdowym.

Rozmówcy zostali także poproszeni o wskazanie słabych stron partnerstw, do których zaliczyli:

- Składane w programie wnioski niekiedy bywają wątpliwe pod kątem realnych korzyści dla przedsiębiorcy, a nawet obu stron. Wiele takich wniosków było obecnych w aplikacjach kilku pierwszych edycji. Obecnie jednak jakość składanych 
wniosków - w ocenie komisji konkursowych poszczególnych edycji - w przeważającej liczbie przypadków jest wysoka lub bardzo wysoka - a wnioski będące bolączką pierwszych edycji pojawiają się już sporadycznie.

- Założeniem programu MOZART jest także zwrotna „korzyść dydaktyczna" dla uczelni, której pracownik bierze udział w programie. Chodzi o wprowadzanie nowych, praktycznych treści do procesu dydaktycznego w postaci nowych programów nauczania, praktyk i staży. Nie zawsze ten element jest wystarczająco eksponowany i praktycznie wykorzystywany przez uczelnie.

- Utrata zaufania między partnerami projektu. Incydentalnie (nie więcej niż w przypadku 1-2\% podpisanych umów) zdarzają się konflikty pomiędzy stronami prowadzące do zaburzenia realizacji celów umowy bądź trudności wskazujące na pogarszającą się jakość realizacji partnerstw, np. poprzez utratę zaufania, co może prowadzić do przeciągających się negocjacji pojednawczych, a nawet do zawieszenia czy rozwiązania umowy.

- Ograniczenie możliwości aplikacji do Programu przez danego przedsiębiorcę do dwóch edycji (przedsiębiorca w okresie czterech lat może uczestniczyć w programie maksymalnie dwa razy; okres czteroletni zaczyna się wraz z edycją w której bierze udział naukowiec).

Reasumując, wskazano cele partnerstw, które są najczęściej osiągane. Zaliczono do nich w kolejności istotności wpływu Programu na partnerstwa:

a) wprowadzenie przez przedsiębiorstwo nowych produktów czy usług,

b) poprawę zarządzania przedsiębiorstwem,

c) wpływ projektu na rozwój kompetencji kadry naukowo-dydaktycznej,

d) nawiązanie bezpośredniego kontaktu między firmami a naukowcami,

e) długoterminową współpracę badawcza

f) realny transfer wiedzy,

g) wpływ projektu na metody dydaktyczne,

h) wpływ projektu na kompetencje studentów i absolwentów,

i) aktywizację wrocławskiego rynku pracy,

j) wzrost zatrudnienia w przedsiębiorstwie. 
W zakończeniu wskazano postulowane kierunki ewolucji Programu w zakresie wsparcia partnerstw na linii nauka-biznes. Respondenci przedstawili kilka działań, które mogłyby zdynamizować jego idee oraz wpłynąć na większe zaangażowanie innych interesariuszy. Są to:

- Możliwość rozszerzenia formuły programu MOZART - a raczej pokrewnych formuł współpracy inspirowanych tym formatem współpracy/partnerstwa, np. na studentów, doktorantów, współpracę z instytucjami publicznymi, pozarządowymi itp.

- Plan stworzenia Klubu Absolwenta Mozarta jako „instytucji” popularyzującej ideę tworzenia partnerstw nauka-biznes.

- Inwentaryzacja obecnie zrealizowanych partnerstw i stworzenie swego rodzaju bazy danych, zasobu wiedzy, który pozwoliłby „zobaczyć się tym, którzy się nie widzą".

- Promocja MOZARTA w ramach innych inicjatyw miejskich, np. w ramach polsko-niemieckich dni innowacji.

- Promocja partnerstw na uczelniach - zaproszenie naukowca i firmy na uczelnie (formuła taka realizowana była w początkach realizacji programu, następnie zastąpiono ją spotkaniami informacyjnymi w urzędzie miejskim; planowany jest powrót do tej formuły ze względu na wyższą wartość informacyjną i promocyjną).

\section{PODSUMOWANIE}

Przytoczone w artykule dane ilościowe oraz procesy wskazują na stale rosnącą rolę miast jako jednego z głównych aktorów w modelach rozwoju społeczno-gospodarczego. Procesy te wzmacniane są działaniami płynącymi z poziomu supranarodowego, a realizowanymi $\mathrm{w}$ ramach procesu integracji europejskiej. Wszystkie najważniejsze instytucje Unii Europejskiej, czyli Komisja, Rada i Parlament coraz częściej wskazują na miasta jako głównych aktorów wszelkiego typu sieci rozwojowych. Te realne działania są opisywane i analizowane w literaturze przedmiotu odnoszącej się do europeizacji jako koncepcje Multi-Level Governance czy sieci polityki.

Aby lepiej zrozumieć i opisać aktywną rolę władz miejskich we współczesnych procesach rozwojowych, pojawiają się nowe lub 
zmodyfikowane koncepcje badawcze, umożliwiające taką analizę. Jednym z nich jest koncepcja samorządu ułatwiającego. Przedstawione tam rozumienie władz samorządowych wskazuje na proaktywną ich rolę, która jest realizowana np. w formie inicjowania partnerstw międzysektorowych, do których angażowani są najważniejsi gracze środowiska lokalnego.

Wykorzystując koncepcję samorządu ułatwiającego, w niniejszym artykule analizie poddano działania władz miejskich Wrocławia, które od 2012 r. realizują Program MOZART. Całkowita wartość alokacji środków budżetowych miasta na tę inicjatywę przez osiem lat jej funkcjonowania wynosi ponad 9 milionów PLN. W tym czasie zainicjowano utworzenie 222 partnerstw na linii nauka-biznes. W ramach partnerstw najczęściej transferowanym rodzajem wiedzy do przedsiębiorstw była wiedza techniczna i ekonomiczna. Partnerstwa na ogół tworzone były przez mikroprzedsiębiorstwa i małe przedsiębiorstwa (blisko 70\%) wszystkich kategorii firm, a także przez pracowników naukowych Politechniki Wrocławskiej i Uniwersytetu Ekonomicznego.

Analizując proces tworzenia i przebiegu Programu, widać wyraźnie, iż aktywność władz miejskich została zainicjowana przez realne potrzeby firm zlokalizowanych we Wrocławiu oraz aglomeracji wrocławskiej. Dodatkowo całość działań została wprzęgnięta w toczące się procesy europeizacji, w których Wrocław aktywnie brał i bierze udział.

Fakt wpisania Programu MOZART do funkcjonalnej Strategii Przedsiębiorczości Miasta wskazuje, że jest to inicjatywa nabierająca cech zakorzenienia instytucjonalnego i trwałości. Została przy tym ukierunkowana na tworzenie otwartego, przyjaznego przedsiębiorczego środowiska, systemowych rozwiązań w zakresie stosowania instrumentów wsparcia zarówno dla dużych inwestorów, jak i dla firm mikro oraz małych i średnich, a także na zbudowanie trwałych form współpracy pomiędzy nauka, administracją i biznesem.

Biorąc ponad to pod uwagę fakt, iż Program MOZART jest jedyną miejską tego typu inicjatywą kształtowania partnerstw naukowo-biznesowych w Polsce, można założyć, że władze Wrocławia wykorzystały szansę płynącą z procesów regionalizacji i integracji, skutecznie absorbując rozwiązania unijne. Co jednak ważniejsze, przeszły ze strategii biernej do antycypacyjnej i obecnie twórczo rozwijają 
Program kreowania powiązań typu government to citizien oraz business to public, co jest potwierdzeniem działań charakterystycznych dla koncepcji samorządu ułatwiającego, a także pozytywną falsyfikacją założonej hipotezy badawczej.

\section{Bibliografia}

Beyme von, K. (2005). Wspótczesne teorie polityczne. Warszawa: Wydawnictwo Naukowe Scholar.

Gilejko, L. i Towalski, R. (2002). Partnerzy społeczni. Konflikty, kompromisy, kooperacja. Warszawa: Poltext.

Kamosiński, S. (2017). Samorząd ułatwiający a obywatelskie powinności biznesu. Płaszczyzny współpracy samorządu terytorialnego i biznesu. Marketing i Rynek, 11.

Komunikat Komisji Europejskiej (2014). Miejski wymiar polityki UE - kluczowe elementy agendy miejskiej. Bruksela: COM (2014) 490 final.

Masse, I., Rajabifard, A. i Williamson, I. (2008). Spatially enabling governments through SDI implementation. International Journal of Geographical Information Science, 22, Issue 1/2008.

Matusiak, K.B. (2001). Zasoby i kierunki rozwoju infrastruktury przedsiębiorczości i transferu technologii. W: K.B. Matusiak, E. Stawasz i A. Jewtuchowicz, Zewnętrzne determinanty rozwoju innowacyjnych firm. Łódź: Wydawnictwo Uniwersytetu Łódzkiego.

Moterski, F. (2010). Idea partnerstwa w procesie rewitalizacji dziedzictwa przemysłowego. Rola jednostek samorządu terytorialnego w budowaniu partnerstwa w ramach koncepcji zintegrowanego zarządzania miastem. Folia Oeconomica. Acta Universitatis Lodziensis 243.

Piattoni, S. (2010). The Theory of Multi-Level Governance: Conceptual, Empirical, and Normative Challanges. Oxford: Oxford University Press.

Puukka, J., Dubarle, P., Goodard, J., Hazelkorn, E. i Kuczera, M. (2013). Higher Education in Regional and City Development: Wroclaw, Poland. OECD Publishing. Pozyskano z: www.oecd.org/publishing/corrigenda (dostęp: 20.02.2020).

Raport Komisji Europejskiej (2011). Miasta przyszłości. Wyzwania, wizje, perspektywy". Bruksela. Pozyskano z: http://ec.europa.eu/regional_policy/sources/docgener/studies/pdf/citiesoftomorrow/citiesoftomorrow_final_pl.pdf ( dostęp: 24.05.2019).

Sassen, S. (1991). Global cities: New York, London, Tokyo. Princeton: University Press. 
Sassen, S. (2012). Cities in a World Economy. Los Angeles: SAGE/Pine Forge Press.

Stone, C. (1998). Theory of Regime Politics - Second Studies. Lawrance: University Press of Kansas.

Strategia Rozwoju Przedsiębiorczości Miasta Wroctawia „Przedsiębiorczy Wrocław 2030". (2019). Wrocław: Urząd Miasta Wrocławia.

Szromnik, A. (2008). Marketing terytorialny. Miasto i region na rynku. Kraków: Oficyna Wolters Kluwer business.

Torfing, J., Peters, B.G., Pierre, J. i Sorensen E. (2012). Interactive Governance. Advancing the Paradigm. Oxford: Oxford University Press.

United Nations, Department of Economic and Social Affairs, Population Division (2014). World Urbanization Prospects: The 2014 Revision, Methodology Working Paper No. ESA/P/WP.238.

Uchwała Rady Miejskiej Wrocławia nr XXIX/652/12 z dnia 5 lipca 2012 roku w sprawie przyjęcia Miejskiego Programu Wsparcia Partnerstwa Szkolnictwa Wyższego i Nauki oraz Sektora Aktywności Gospodarczej „MOZART”.

Vlachopoulou, M. i Manthou, V. (2003). Partnership Alliances In Virtual Markets. International of Physical Distribution and Logistics Management, 33, no. 3 .

\section{Copyright and License}

This article is published under the terms of the Creative Commons Attribution - NoDerivs (CC BY- ND 4.0) License http://creativecommons.org/licenses/by-nd/4.0/ 